\title{
ENVIRONMENT AND THE SOMATIC BODY IN CHERRÍE MORAGA'S HEROES AND SAINTS AND EDWIDGE DANTICAT'S THE FARMING OF BONES
}

\author{
BABETT RUBÓCZKI \\ University of Debrecen, Hungary. \\ babett.ruboczki@gmail.com
}

Received 15 July 2020

Accepted 12 February 2021

KEYWORDS: postcolonial ecocriticism; disrupted bodies; toxicity; environmental racism; memory; rupture; Glissant

PALABRAS CLAVE: eco-critica poscolonial; cuerpos en disputa; toxicidad; racismo ambiental; memoria; ruptura; Glissant

\begin{abstract}
The paper offers a cross-cultural literary analysis of Chicana Cherrie Moraga's Heroes and Saints (1992) and Haitian American Edwidge Danticat's The Farming of Bones (1998) and compares the play and the novel on the basis of their shared thematic link of interwoven environmental and racial violence directed against marginalized people of color. Despite the works' geographically distant contexts - set in the US Southwest and the Caribbean island of Hispaniola, respectively-and the differing collective traumas of genocide the texts dramatize, both narratives foreground the motif of violated nature as a primary critical lens to unveil and critique the ongoing practices of colonialism permeating twentieth-century US and Caribbean politics. The interlocking images of women-of-colors' disfigured bodies and the environmental devastation caused by (post)colonial violence underline the pervasiveness of harm done to both the earth and the somatic body.
\end{abstract}

\section{RESUMEN}

Este artículo ofrece un análisis intercultural de la obra de teatro Heroes and Saints (1992) de la chicana Cherrie Moraga y de la novela The Farming of Bones (1998) de la haitiano- 
americana Edwidge Danticat, así como una comparación de ambas en base a la temática en común sobre violencia medioambiental y racial dirigida a personas de color marginadas. A pesar de la distancia geográfica entre las dos obras, ambientadas, respectivamente, en el Suroeste de Estados Unidos y la isla caribeña de La Española y los distintos traumas colectivos sobre genocidio que los textos escenifican, las dos narraciones tienen como tema central la naturaleza profanada como perspectiva crítica primaria para descubrir y analizar las prácticas colonialistas de la politica estadounidense y caribeña del siglo XX. Las imágenes entrelazadas de cuerpos desfigurados de mujeres de color y la devastación medioambiental causada por la violencia (pos)colonial ponen de manifiesto la generalización del daño perpetuado tanto a la tierra como al cuerpo.

\section{LAND, BODY, HISTORY: METHODOLOGY AND CONTEXT}

Cherrie Moraga's Heroes and Saints (1992) and Haitian American Edwidge Danticat's The Farming of Bones (1998) are dominated by agricultural landscapes portrayed as memorial sites of actual historical injustice committed against both land and people. Moraga juxtaposes the play's setting of the pesticide poisoned Californian vineyards with somatically dysfunctional and disabled bodies of young children. Apposing images of contaminated bodies and environment, Moraga calls awareness to the environmentally racist politics of the 1980 s American corporate businesses that sprayed carcinogenic fertilizers on farmlands cultivated by Mexican American laborers. Similarly, Danticat aligns somatic wounds and infant mortality with images of the Dominican sugarcane plantation to bear testimony to the political genocide of the 1937 Parsley Massacre when more than 20,000 Haitians laboring in Dominican sugarcane fields were ordered to be murdered by Dominican dictator Rafael Leonidas Trujillo.

I argue that the political histories of ethnic and racial violence cannot be disentangled from the materiality of environmental and corporeal harm. The postcolonial exploitation of human and the nonhuman environment, which is comparable and linkable in the selected narratives, substantiates a postcolonial ecocritical approach that I apply as my central theoretical framework. Concerned with exploring intersections between historical conditions of colonialism 
and the environmental modes of subjugating and manipulating flora and fauna, postcolonial ecocriticism is a suitable methodological tool to demonstrate the mutually constitutive view of ecological and historical violence in the selected texts. I examine Heroes and Saints and The Farming of Bones as postcolonial narratives, which express an underlying political criticism toward the respective twentiethcentury histories of social and environmental injustices committed against Chicanas and Haitians. The authors' engagement in a decolonial project to write the politically silenced stories of the corresponding ethnic communities also underscores the categorization of these works as postcolonial literatures.

My analytical framework relies on Western ecocritical scholar Stacy Alaimo's notion of trans-corporeality as expounded in her volume, Bodily Natures: Science, Environment, and the Material Self (2010), and Caribbean postcolonial scholar Édouard Glissant's concept of "the aesthetics of rupture" explicated in his seminal works, Caribbean Discourse (1989) and Poetics of Relation (1990). Alaimo's and Glissant's shared departure point to challenge the nature/culture divide and re-conceptualize the human and nonhuman worlds as inherently relational highlights a potential dialogic relationship between Alaimo's global ecocritical perspectives and Glissant's regional postcolonial polemics. From an ecocritical point of view, both conceptual frameworks challenge anthropocentrism; the Western perception that nature is devoid of and external to human culture and, thus, the environmental activity of humans has no direct effect on social and cultural processes. As such, Alaimo's and Glissant's notions are proper analytical means to elucidate that the environmental images in the texts are not limited to material, vegetative forms that provide an inert setting to the plot, but unveil their inherent embeddedness in historical realities.

While my underlying methodology is to highlight the dialogue between Alaimo and Glissant, I wish to avoid one of the most frequent pitfalls of contemporary postcolonial ecocriticism and efface the culturally specific understandings of landscapes, and the political subjectivities the particular geopolitics of these landscapes can enable (Huggan and Tiffin 10, DeLoughrey and Handley 28). The landscapes Moraga and Danticat present are nested in diverging cultural mythologies and diverse histories of political violence, which consequently, render different meanings to the physical scars these traumas leave on the protagonists' bodies. To highlight that the political and spiritual origins of ecological issues are always 
culturally-anchored, I approach the selected texts through Alaimo's and Glissant's concepts, respectively. I read the poisoned farms in Moraga's play through Alaimo's notion of trans-corporeality, and explore Danticat's novel on the Caribbean colonial legacies of the planation system of slavery via the lens of Glissant's relational view of ecologies and national histories.

TOXIC BODIES AND THE POISONED MOTHERLAND IN HEROES AND SAINTS

The toxin-laden, sick bodies of Mexican Americans are pivotal somatic images in Heroes and Saints. Moraga's portrayal of the poisoned bodies makes emphatic the reality of pain caused by symptoms of bodily distortions and disability that the chemical substance imposes on the bodies who come into contact with the infected soil and water.

However, toxicity in the play does not remain reduced to its conventional medical understanding and serves as a discursive lens through which Moraga severely critiques the American government's economic exploitation and political oppression of Chicano/a people. Mexican American César Chávez's life-long political activism, his leadership of the Chicano Movement between the 1960s and 1980s, and his fight for Mexican farmworkers' human and labor rights provide the socio-political context of Heroes and Saints. Pivotal events in the history of Chicano Movement, including the 1960s grape boycott protests, Chávez's thirty-six-day fast, and the brutal beating of the co-leader of the union for Mexican farmworkers, Dolores Huerta at a press conference are all re-enacted on stage. Raising awareness to Chicano/a farmworkers' plight, the play claims relationship to El Teatro Campesino, the grassroot Chicano theatrical tradition emerging in 1965, which draws on the lived, yet, silenced realities of the Chicano farmworker community.

The play's connection to El Teatro and its political background of mobilizing the Chicano community to challenge US politics are also evidenced by the fact that Moraga was heavily influenced by the 1986 documentary, The Wrath of Grapes, a production by the United Farm Workers of America. The short film served to promote Chávez's 1986 campaign, "Wrath of Grapes," which aimed to expose the environmentally racist politics of the US, and educate the general public about the health risks of pesticides used in corporate-run agricultural food production (Zapata 49). Underlining how environmental injustice figures into the social, 
cultural, and economic subjugation of Mexican Americans, the documentary graphically presents the various sicknesses wreaked upon the Chicano/a farmworker families, who were exposed to a disproportionate amount of poisonous insecticides during their daily labors on the fields. The toxic chemicals infiltrated soil, water, human skin, and could be traced in the mothers' milk. Due to the extraordinarily high number of severe birth defects and children's deaths by leukemia, the American valley town of McFarland was declared a cancer cluster (Davies 31). Set in the fictional town of McLaughlin, a Californian agricultural town of San Joaquin Valley, the play bears testimony to the interconnected forms of social, political, and environmental injustices that the Mexican American families of McFarland endured.

Juxtaposing the poisoned body and contaminated land, the play enacts Alaimo's perception of the toxic body as a conceptual metaphor of trans-corporeal space in which "the material cannot be disentangled from networks that are simultaneously economic, political, cultural, scientific, and substantial" (20). The permeability of the chemical toxin that engenders a thin boundary and close-toskin encounter between the soil and the workers underlines the phenomenological interconnectedness of ill bodies and ill nature. Moraga's stage instructions for the setting imply this connection:

The hundreds of miles of soil that surround the lives of Valley dwellers should not be confused with land. What was once land has become dirt, overworked dirt, over-irrigated dirt, injected with deadly doses of chemicals and violated by every manner of ground- and back-breaking machinery. The people that work the dirt do not call what was once the land their enemy. They remember what land used to be and await its second coming. (333)

The exposure of the farmworkers' bodies to the contaminated dirt elucidates the shared vulnerability of landscape and humans to economic exploitation and underlies how both people of color and the soil are rendered exhausted and ill due to the excessively high toxic load they carry.

The quotation also underscores that the consequences of the environmentally racist politics of twentieth-century American agricultural politics far exceed the biopolitical exploitation of marginalized Latino/as. The chemical poisoning of the vineyards also violently exploits and allegorically breaks the Chicano/a 
community's primordial spiritual tie to the land, which beyond providing labor and food source, also figures as a repository of collective cultural memory. The preservation of the land's memory and its "second coming" (333) in the quotation above allude to Chicano/as' ancestral homeland, Aztlán, which was seized by the American government after the 1848 Treaty of Guadalupe Hidalgo that officially ended the Mexican-American War (1846-48). Thus, the chemically induced harm, which simultaneously ruptures the ecology and the human body, mirrors Mexican Americans' primary historical wound of land loss and being subsequently viewed by US politics as unwanted border citizens.

Moraga's wheelchair-bound protagonist, the teenager Cerezita Valle-who is a head without body and was born without limbs due to the toxic pollution that affected her mother's womb-epitomizes the interlacing web of environmental, health, gender, and social injustices. Cerezita's chemical-permeated body can be read as a critical site of trans-corporeality. Moraga's stage instructions establish an unusual association between the character's material reality of somatic injury and her more-than-human, spiritual qualities of feminine beauty:

CEREZITA is a head of human dimension, but one who possesses such dignity of bearing and classical Indian beauty she can, at times, assume nearly religious proportions $[\ldots]$ This image, however, should be contrasted with the very real "humanness" she exhibits on a daily functioning level. (332-33)

This atypical embodiment endows Cere with the ability to straddle the rift between her dispossessed "natural" body and her mestiza Indian cultural identity that legitimates her ancestral tie to the land. Her liminal subjectivity, located in-between the material and spiritual spheres, distinguishes her from the other members of the farmworkers community who are alienated from the poisoned land and, consequently, from their collective cultural identity that bonds them to the soil. Cerezita's simultaneously spiritual and material representation re-signifies her passive, paralyzed body as an active agent in reestablishing the tie between people and land that the chemical injected to the soil severed.

In one of the last scenes of the play, Cerezita figuratively heals the breach engendered by the toxin, and re-members the people and the violated land. At the end of the play, she takes the 
initiative to act against the American oppression of her community. Instead of organizing a political protest, Cerezita opts for ritually sacrificing herself in the middle of the fields and lets the toxinspraying helicopters shoot her from above. Preceding her sacrificial act, during which she personifies the Virgin of Guadalupe, she addresses the people as follows:

Put your hand inside my wound. Inside the valley of my wound, there is a people. A miracle people. In this pueblito where the valley people live, the river runs red with blood; but they are not afraid because they are used to the color red. It is the same color as the river that runs through their veins, the same color as the sun setting into the sierras, the same color of the pool of liquid they were born into. [...] You are the miracle people because today, this day, that red memory will spill out from inside you and flood this valley con coraje. And you will be free. Free to name this land Madre. Madre Tierra ... (374)

Correlating the poisoned life blood the valley inhabitants and the soil share, Cerezita enters into a dialogue with the violated environment and reestablishes the connection between Chicano/as and the land as their native motherland. By reconfiguring her bodily difference from a personal to a collective wound that interweaves sick bodies and the toxic environment, Cerezita exemplifies Alaimo's notion of trans-corporeality. At the moment of her speech, she develops a trans-corporeal consciousness of her self by understanding-and making the pueblo people also comprehend-"the extent to which the substance of the human is ultimately inseparable from the environment"' (Alaimo 2). The protagonist's disrupted body, thus, transforms into a decolonial site of social change which-by reinstating the nature-culture dialect the toxin interrupted-gestures toward the liberation of Mexican Americans from postcolonial power systems of subjugation.

The play stages another mode of bodily resistance against the environmentally racist US culture. It represents the quite macabre practice of the public crucifixions of small children who died as a result of the pesticide poisoning. The performative crucifixions of dead babies taking place in the middle of the toxic farmlands further underlines that the agricultural landscape in the play functions not merely as a theatrical backdrop to the Chicano people's plight. The land becomes a politicized geography, as it exposes the histories of racial hierarchies that render Mexican American communities inferior and disposable in the US. I share Linda Margarita 
Greenberg's argument on the "pedagogy of crucifixions" (170) with which, according to Greenberg, Moraga's play performs an alternative, corporeal form of resistance against racialized systems of power by reconfiguring the dead as not segregated from, but interacting with the living human and non-human environment (170-171). The indissoluble bond between bodies, history, and nature that Moraga stages resonates with Danticat's postcolonial portrayal of nature as a repository of painful memories related to political histories of collective and personal dispossessions.

\section{SOMATIC WOUNDS, NATURE, AND RACIAL POLITICS IN THE FARMING OF BONES}

Drawing on interlacing images of violated bodies and soils, Danticat's novel shares with Moraga's play an apprehension of and pointed critique against postcolonial ethno-racial politics, which in the Caribbean context of the novel harks back to the colonial era's "coevolution of dominating nature and human beings through racially hierarchized 'natural Histories"' (Braziel 111). In Danticat's work, the central environmental image of the sugarcane plantation evokes the sixteenth-to-nineteenth-century transatlantic slave trade-the practice of mass-scale transplantation and settlement of enslaved Africans to the Americas-that Glissant identifies as the primary rupture in Caribbean cultural memory. As the postcolonial scholar advances, the slave trade established the foundations of Caribbean history on a pervasive sense of alienation from nature, as the land became associated with forced labor and the black subjects' genocidal subjugation (Caribbean Discourse 154). Consequently, the black population's dislocation made impossible for the following generations to "relate [...] a mythological chronology of this land to their knowledge of the country, so nature and culture have not formed a dialectical whole" (63).

In the Introduction to Caribbean Literature and the Environment: Between Nature and Culture, Elizabeth M. DeLoughrey and the co-editors of the volume recognize Western historiography as the main contributor to the dialectical rupture between Caribbean cultural and natural histories (3). To contest the ahistorical approach of Western philosophical thought to Caribbean geographies, the book aligns its postcolonial ecocritical approach to literary texts with Glissant's notion of "the aesthetics of earth." Glissant's concept resides in his perception that the poetic evocation of the natural 
environment as a site of historical trauma restores the politically disrupted ties between nature and culture, the environment and the human subject (Poetics of Relation 151). As he points out, the memorial engagement with the multiple experiences of ruptures in the Caribbean history are, ambiguously, regenerative; they enable the reconnection with the Caribbean land as a geographic marker of cultural belonging and identity.

Illustrating how historical injustices are mapped on both bodies and landscapes, Danticat's novel conveys Glissant's ultimately affirmative concept of rupture as an aesthetic mode of resistance against the erased link between cultural and natural histories of violence. The novel's title, The Farming of Bones, prefigures the underlying interplay of ecocide and genocide as defacing, close-to-skin experiences. On the one hand, the image of "bones" conjures the historical rupture Glissant associates with the Middle Passage, the colonial slave trade route across the Atlantic Ocean, which is scattered with the skeletal remains of numerous captive Africans who did not survive the voyage to the Caribbean islands. On the other hand, the novel is abundant of images depicting how harvesting the sugarcane often causes deep cuts in the skin, which leaves "a map of scars" (Danticat 62) on farmworkers' bodies. Therefore, the bone like sharpness of the agricultural plant serves as a particularly appropriate botanical symbol for Danticat to portray the sugarcane as a daily bodily reminder of black Haitians' marked racial inferiority in the Dominican side of Hispaniola. The title also recalls the 1937 massacre when "many human beings [were] cut down like mere stalks of sugarcane at harvest time" (Wucker qtd. in Hewett 127). This juxtaposition of colonial and postcolonial histories of racial violence is an underlying aspect in both Moraga's and Danticat's works and illustrates the ongoing colonial logic that entangles the domination of land with the physical subjugation of humans.

Danticat's recurrent use of the motif of the sugarcane as an allegorical symbol of Caribbean historical traumas related to cultural dispossession and racial subjugation of blacks reflects Glissant's ecopoetic formulation of rupture as both a thematic and formal feature of the novel. As Glissant argues, due to the violent "ruptures [...] that began with a brutal dislocation, the slave trade" (Caribbean Discourse 61), the Caribbean historical consciousness reflects a "tormented chronology," which defies linear progression and, instead, highlights that the traumatic past continuously haunts the present 
(65). In the novel, the "tormented chronology" characterizing Caribbean history is expressed through non-linear storytelling. The protagonist, Amabelle Desiré's retrospective narration of her own story is structured as a dialogue between her present and past selves. Presenting a stream of consciousness mode of narration, the chapters alternate between Amabelle's hallucinations and haunting reminiscences of Haiti (the geography signifying her homeland and lost family) and the Dominican Republic, where she works as a domestic servant for a white elite Dominican family. The novel starts with Amabelle assisting her mistress, Señora Valencia, in delivering the twins Rafael and Rosalinda. The abrupt death of the few-days-old infant, Rafael, temporally overlaps with the first day of the new harvest season.

Just then the cane harvest began: the first moment saw the fires set to clear the fields, singeing the leaves off the cane stalks before they could be chopped down. Clouds of thick white smoke blanketed the sky. The smell of burning soil and molasses invaded the air, dry grass and weeds crackling and shooting sparks, vultures circling low looking for rats and lizards escaping the blaze. (86)

The natural images of death that ominously foreshadow the white Dominican newborn baby's demise mark the end of a human life while, at the same time, indicates the beginning of new cycle in nature, the harvest time of the sugarcane. The interplay of death and birth in this harvest scene illustrates the interaction between "rupture and connection" that Glissant views as inherently embedded in his notion, "the aesthetics of earth" (Poetics of Relation 151). The portrayal of the baby boy's death signals an emotionally rupturing and traumatic experience for the family. Yet, in a Glissantian mode, this familial trauma has the potential to reveal the inseparably intertwined issues of race and ecology that are often eroded in Western historical accounts of the Caribbean.

Comparably to Moraga's images of dead children as the politicized locus of the play (Greenberg 164-65), in Danticat's novel Rafael's death is political, and marks the haunting presence of racial hierarchies, which sharply contrast the black Haitians with the white-washed identity of the Dominican elite. However, as Janice Spleth clarifies, "Danticat produces numerous episodes to show that racial identities are far from clear as Haitians are mistaken for Dominicans and vice versa, and Señora Valencia's twin babies 
emphatically demonstrate that race, as a category, is highly problematic" (148). The ambiguous racial distinctions that fuel the hatred between Haitians and Dominicans are evidenced by the fact that it is Rafael's twin sister, the bronze-colored Rosalinda, who survives. Her darker skin color, however, constitutes a taboo subject from the very beginning of her birth, which makes her the symbol of the Dominican elite's uncanny fear of being contaminated by "the racial Other," who should be silenced and suppressed. Thus, while the quoted image of the burning sugarcane field seems to underline the sharp geographical (and racial) demarcation line between Senora Valencia's family and the cane cutters, Danticat's depiction of the death of a Dominican child uncovers the ambiguity of this separation and unsettles the normative discourse of rigid racial distinctions.

Interlinking the burning cane with genocidal acts of burning Haitian bodies, the novel expands the metaphoric meaning of the sugarcane bonfire and utilizes it as a poignant metaphor of the Trujillo regime's ethnic cleansing. The suffocating air related to the beginning of the sugarcane harvest haunts a later scene in the novel when, fleeing from the Dominican soldiers, Amabelle tries to cross the Dajabón (Massacre) River, a natural border between the Dominican Republic and Haiti. Spending a night in the woods hiding from Dominican soldiers, Amabelle recalls the smell of the burning sugar fields, which she now associates with the genocide of her people:

There was no mistaking the stench toward us. It was the smell of blood sizzling, of flesh melting to the last bone, a bonfire of corpses, like the one the Generalissimo had ordered at the Plaza Colombina to avoid the spreading of disease among the living after the last great hurricane. (181)

The recurring motif of fire that separates human flesh from the bone eerily resonates with "singeing the leaves off the cane stalks" (86) in the initial harvest scene. The analogy between the chopped sugarcane and the somatic bodies stripped to their skeletal bones elucidates an underlying postcolonial ecocritical imagery in Danticat's work which highlights the Dominican government's colonial legacy regarding the racial subjugation of Haitians.

The trope of disability and bodily distortion as metaphors of the oppressed ethnic communities' political paralysis are central motifs in both Moraga's and Danticat's works. In a similar manner to 
Moraga's disfigured female protagonist, Danticat foregrounds the Haitian orphan, Amabelle's scarred and disintegrated body as a critical space to make palpably visible the relationship between the rupturing effects of ecological and historical violence in the Caribbean region. At the beginning of the novel, Amabelle is only an observer of the mutilating effects of the economic exploitation mapped on Haitian women's bodies. She takes part in the morning ritual performed by the cane cutters and their relatives who take a bath in the river before starting the daily work. Amabelle observes the women standing around her in the water.

There were women in the stream who were ancient enough to be our great-grand-mother [...] Among the oldest women, one was missing an ear. Two had lost fingers. One had her right cheekbone cracked in half, the result of a run-away machete in the fields. (61)

Amabelle shares the collective wound these women's disabled bodies signify, as she also becomes the victim of border violence. In her attempt to escape through the Massacre River, Amabelle is seriously beaten up by a Dominican mob. The brutal incident leaves enduring scars on her body: her knees could not bend and her jaw becomes misaligned, which impedes her ability to speak. Taken to a border hospital after suffering severe injuries, Amabelle perceives several truncated bodies around her that she envisions as mutilated trees:

I was taken past a line of people with burns that had destroyed most of their skin, men and women charred into awkward poses, arms and legs frozen in mid-air, like tree trunks long separated from their branches. (206)

The pervasive images of Haitian victims' somatic injuries and dismemberments reverberate with Glissant's perception of the Caribbean's history as characterized by ruptures and dislocations.

Amabelle, however, reconfigures the intertwined effects of historical and physical rupture the border river signifies when many years after her injury she revisits the river. Lying still in the water, her distorted body establishes a physical contact with the same body of water that carries the collective memories of slaughtered Haitians and her personal traumatic memories regarding the loss of her parents, who drowned in the same river when she was a child. Thus, Danticat aestheticizes the river as a powerful environmental symbol 
that merges different temporalities of historical and personal traumas through images of bodily contact.

The encounter of Amabelle's body with the wounding memory of the river toward the end of the novel has a transformative potential. Danticat narrates Amabelle's reconnection with the personal and collective site of trauma as peaceful and soothing. At the end of the novel the river is conveyed as a sanctuary in which Amabelle feels like "cradled by the current", sensing a "gentler embrace" and "relief from the fear of mudslides and blood bubbling out of the riverbed, where it is said the dead add their tears to the river flow" (310). Although Amabelle's re-entering the river does not engender the recuperation of her own body, her bodily contact with the water performatively heals the dialectical rift between nature and culture, past and present, personal and collective wounds. Thus, simultaneously being a victim and the healer of the mutilating effects of historical violence aligns Amabelle with Glissant's postcolonial notion that literature has the power to address the ruptures in Caribbean history by re-membering with and re-writing ecological sites of trauma.

\section{CONCLUSIONS}

Portraying distinct ethnic histories of postcolonial violence simultaneously committed against human bodies and the environment, Heroes and Saints and The Farming of Bones share an ecopoetic sensibility. Both texts foreground ecological and agricultural images as aesthetic strategies of resistance against postcolonial modes of genocide targeting Mexican Americans in the US Southwest, and Haitians in the US Caribbean. Both texts raise awareness to the pervasiveness of human rights violations that continue to affect racially marginalized groups even in the postcolonial era of the twentieth century. Moraga's play stages the American government's chemically induced poisoning that specifically targeted Mexican American vineyards in the 1980s, while Danticat dramatizes the 1930s Dominican regime's systematic political massacre of black Haitian cane cutter communities. The ecological approach applied to the texts-which are interpreted through the critical lens of Alaimo's concept of trans-corporeality and Glissant's notion of "the aesthetics of rupture"-reinforces that the somatically dysfunctional, sick, and violently ruptured bodies exposed in both works function as rhizomatic spaces, interlinking 
the physical, mental, environmental, and political implications of colonial brutality. Therefore, Moraga's and Danticat's dialogical portrayal of environment and human bodies transcends being merely an aesthetic exercise to unveil historical traumas. In both works the utilization of environments and plants as metaphors of dispossession of land and racial subjugation can be read as a decolonializing "aesthetics of the earth." The distorted bodies of the female protagonists, Cerezita and Amabelle, are particularly instrumental in bringing forth this decolonial dimension of the narratives. Both are endowed with the potential to figuratively re-member the bond between nature and culture, past and present, environment and the somatic body, as well as bridge the ruptures established by the injustices committed against Chicanas and Haitians.

\section{WORKS CITED}

ALAIMO, Stacy. Bodily Natures: Science, Environment, and the Material Self. Indiana UP, 2010.

BRAZIEL, Jana Evans. "'Caribbean Genesis:' Language, Gardens, Worlds (Jamaica Kincaid, Derek Walcott, Edouard Glissant)." DeLoughrey et al., pp. 110-126.

DANTICAT, Edwidge. The Farming of Bones. Abacus, 1999.

DAVIES, Telory W. "Race, Gender, and Disability: Cherrie Moraga's Bodiless Head." Journal of Dramatic Theory and Criticism, vol. XXI, no. 1, 2006, pp. 29-44.

DELOUGHREY, Elizabeth, et al. Caribbean Literature and the Environment: Between Nature and Culture. University of Virginia Press, 2005.

DELOUGHREY, Elizabeth, and George B. Handley, editors. Postcolonial Ecologies: Literatures of the Environment. Oxford UP, 2011.

GLISSANT, Édouard. Caribbean Discourse: Selected Essays. University of Virginia Press, 1989.

---. Poetics of Relation. University of Michigan Press, 1997.

GREENBERG, Linda Margarita. "Learning from the Dead: Wounds, Women, and Activism in Cherrie Moraga's Heroes and Saints." MELUS, vol. 34, no. 1, 2009, pp. 163-184. 
HEWETT, Heather. "At the Crossroads: Disability and Trauma in "The Farming of Bones." MELUS, vol. 31, no. 3, 2006, pp. 123-145.

HUGGAN, Graham, and Helen Tiffin. Postcolonial Ecocriticism: Literature, Animals, Environment. Routledge, 2015.

MORAGA, Cherrie. Heroes and Saints. Contemporary Plays by Women of Color: An Anthology, edited by Kathy E. Perkins and Roberta Uno. Routledge, 2005, pp. 332-378.

SPLETH, Janice. "Narrating Genocide: Edwidge Danticat's The Farming of Bones and Yolande Mukagasana's N'aie pas peur de sa voir." West Virginia University Philological Papers, vol. 54, 2011, pp. 144-150

ZAPATA, Claudia. "Branding 'Death' in a High-Tech Boycott: United Farm Workers and the Wrath of Grapes Campaign." Journal of Latino/Latin American Studies, vol. 10, no. 1, 2019, pp. 48-69. 